\title{
ANALISIS DAN PERANCANGAN SISTEM INFORMASI ADMINISTRASI PEMBAYARAN BIAYA PENDIDIKAN BERBASIS WEB DAN SMS GATEWAY PADA PONDOK PESANTREN NURUL IMAN MUARO SEBAPO
}

\author{
$\underline{\text { Ahmad Husna Ahadi }{ }^{1} \text {, Effiyaldi }}{ }^{2}$ \\ Program Studi Magister Sistem Informasi, STIKOM Dinamika Bangsa, Jambi \\ Jl. Jendral Sudirman, Kec. The Hok, (0741) 35095 \\ E-mail: husna3305@gmail.com ${ }^{1}$, effiyaldi67@ stikom-db.ac.id ${ }^{2}$
}

\begin{abstract}
Pondok Pesantren Nurul Iman is a religious education institution that has a number of santri as 621 people. In the administrative activities of the payment education fees at Pondok Pesantren Nurul Iman still use manual recording system that experienced various obstacles such as the length of time required to get information on payment of education fee and often the information is not up to the parents of the santri. Therefore, need a tool in the form of Information Administration System Payments Education Fee that work in computerized, so that can be a solution of the problem. In this research, system design using UML modeling that produce use case diagram, activity diagram and class diagram. The results of this research is a prototype of the Information System Administration Payment Education Fees based web and SMS Gateway in the hope to help overcome the problems that occur.
\end{abstract}

Keywords: Information System, Payment Administration, UML, SMS Gateway, web

\begin{abstract}
Abstrak
Pondok Pesantren Nurul Iman adalah lembaga pendidikan keagamaan yang memiliki jumlah santri sebanyak 621 orang. Dalam kegiatan administrasi pembayaran biaya pendidikan di Pondok Pesantren Nurul Iman hingga saat ini masih menggunakan sistem pencatatan manual yang mengalami berbagai kendala seperti lamanya waktu yang diperlukan untuk mendapatkan informasi pembayaran biaya pendidikan dan sering informasi tersebut tidak sampai kepada orang tua dari para santri. Oleh karena itu maka diperlukan suatu alat bantu berupa Sistem Informasi Administrasi Pembayaran Biaya Pendidikan yang berkerja secara terkomputerisasi, sehingga bisa menjadi solusi dari permasalahan tersebut. Dalam penelitian ini, perancangan sistem menggunakan pemodelan UML yang menghasilkan use case diagram, activity diagram dan class diagram. Hasil penelitian yang dilakukan ini berupa prototype dari Sisem Informasi Administrasi Pembayaran Biaya Pendidikan berbasis web dan SMS Gateway dengan harapan dapat membantu mengatasi permasalahan yang terjadi.
\end{abstract}

Kata kunci: Sistem Informasi, Administrasi Pembayaran, UML, SMS Gateway, web

(C) 2019 Jurnal Manajemen Sistem Informasi

\section{Pendahuluan}

Kemajuan ilmu dibidang teknologi informasi sangat cepat dirasakan pada masa sekarang ini. Hal ini dapat dilihat dengan semakin mudah dan cepatnya manusia dalam memperoleh informasi yang dibutuhkan. 
Semakin mudahnya manusia dalam memperoleh informasi tidak terlepas dari banyaknya media pendukung informasi (perangkat) seperti internet, telepon seluler (ponsel), televisi, radio, surat kabar, majalah dan lain - lain. Salah satu perangkat yang saat ini banyak digunakan adalah ponsel. Selain digunakan untuk komunikasi suara dengan lawan bicara, ponsel juga memiliki kemampuan lain yaitu dapat digunakan untuk mengirim pesan teks yang lebih populer dengan nama SMS (Short Message Service). Dengan semakin banyaknya penggunaan ponsel untuk berkirim $S M S$, kemudian muncul gagasan untuk membuat layanan berbasis SMS sepeti info berita, transaksi perbankan, kuis, polling dan lain sebagainya. Layanan berbasis SMS ini juga di ikuti oleh lembaga pendidikan yaitu sekolah, perguruan tinggi, dan lain sebagainya.

Pondok Pesantren Nurul Iman yang beralamat di Desa Muaro Sebapo Kecamatan Mestong Kabupaten Muaro Jambi adalah lembaga keagamaan berbasis pesantren yang didirikan pada tahun 1996 Oleh KH. Sochieb dan Ibu Nyai Hj. R.A Siti Bachriah Al Khafidzah dengan berdasarkan keinginan untuk menegakkan syiar agama islam. Awalnya para santri yang ada di Pondok Pesantren Nurul Iman adalah anak-anak yang berada di Desa Muaro Sebapo tersebut dan beberapa anak dari desa tetangga. Lambat laun santri bertambah banyak dan datang dari berbagai daerah. Diantaranya dari Sungai Bahar, Petaling, Singkut, Ladang Panjang kecamatan lainnya dan sudah menyebar di seluruh Kabupaten yang ada di Jambi bahkan dari provinsi tetangga seperti Riau, Bengkulu, Padang, Medan dan Palembang.

Kini Jumlah santri pondok pesantren Nurul Iman adalah 621 santri dengan berbagai tingkatan mulai dari tingkat SMP dan SMA. Dengan berbagai macam tingkatan dan jumlah santri yang tidak sedikit, maka petugas Tata Usaha (TU) yang menangani administrasi pembayaran biaya pendidikan santri seringkali mengalami banyak kendala dalam menjalankan tugasnya.

Tata Usaha (TU) di Pondok Pesantren Nurul Iman dalam kegiatan administrasi pembayaran biaya pendidikan hingga saat ini masih menggunakan sistem pencatatan manual yang tentu saja mengalami berbagai kendala. Kendala yang paling sering dirasakan adalah petugas mengalami kesulitan dalam hal pencatatan dan pelaporan kepada pimpinan. Kendala lain yang muncul adalah pencarian data pembayaran santri membutuhkan waktu yang cukup lama dikarenakan data pembayaran dicatat pada sebuah buku sehingga petugas harus mencari data satu persatu.

Saat ini informasi pembayaran hanya disampaikan kepada santri. Kemudian santri menyampaikan kepada orang tua atau walinya. Terkadang ada beberapa santri tidak menyampaikan informasi ini kepada orang tua atau walinya. Sehingga orang tua atau wali santri tidak mengetahui informasi tentang pembayaran tersebut. Hal ini berdampak pada pembayaran santri yang banyak terjadi tunggakan pembayaran. Oleh karena itu maka diperlukan suatu alat bantu berupa Sistem Informasi Administrasi pembayaran biaya pendidikan yang berkerja secara terkomputerisasi, sehingga bisa menjadi solusi dari permasalahan tersebut. Dimana Sistem Informasi dirancang berbasis web dan mendukung fitur sms gateway.

\section{Tinjauan Pustaka/Penelitian Sebelumnya}

Penelitian sejenis yang pernah dilakukan adalah Pembangunan Sistem Informasi Administrasi Pembayaran Siswa Madrasah Aliyah Ma'arif Pacitan oleh Ali Syahbana. Penelitian lain adalah Sistem Informasi Pembayaran SPP Berbasis Web Dan SMS Broadcast (Studi Kasus: SMP Muhammadiyah 03 Semarang) oleh Mafrida Rofiul Hayati, Migunani dan Fitro Nur Hakim serta Sistem Informasi Pembayaran Biaya Pendidikan Siswa Pada SMK Perwira Bangsa Bekasi oleh Merza Dheo Prakoso dan Herlawati.

Penelitian yang dilakukan oleh Ali Syahbana membahas tentang perancangan sistem dan pendekatan menggunakan DFD sedangkan pada penelitian tesis ini menggunakan model $U M L$. Selain itu pada penelitian yang dilakukan oleh Ali Syahbana bahasa pemrograman yang digunakan adalah Bahasa Pemrograman Visual Basic.Net.

Penelitian yang dilakukan oleh Mafrida Rofiul Hayati, Migunani dan Fitro Nur Hakim tentang sistem informasi pembayaran SPP berbasis web dan sms broadcast (Studi Kasus: SMP Muhammadiyah 03 Semarang) bertujuan untuk memberikan solusi dalam proses pembayaran SPP siswa agar dapat dikelola dengan baik dan mengurangi terjadinya keterlambatan pembayaran siswa melalui fasilitas SMS broadcast kepada orang tua atau wali perihal pembayaran SPP.

Sedangkan Sistem Informasi Pembayaran Biaya Pendidikan Siswa Pada SMK Perwira Bangsa Bekasi oleh Merza Dheo Prakoso dan Herlawati bertujuan untuk mempercepat pencarian data transaksi yang sudah lama, pencatatan transaksi menjadi lebih lebih cepat dan akurat, tidak terjadi penumpukan buku transaksi dalam rak buku serata pembuatan laporan transaksi akan lebih akurat dan proses pembayaran

Jurnal Manajemen Sistem Informasi Vol.4, No.2, Juni 2019 
iuran siswa semakin cepat dan efesien serta mempercepat kinerja staff tata usaha sekolah dalam melayani orang tua atau siswa yang ingin melakukan pembayaran sekolah.

Penelitian yang akan penulis lakukan memiliki relevansi dengan penelitian yang dilakukan oleh Ali Syahbana dalam permasalahan penelitian yaitu sama-sama mengangkat tentang sistem informasi pembayaran.Sedangkan perbedaan penelitian Ali Syahbana dengan penulis yaitu untuk menggambarkan fungsionalitas sistem informasi, penelitian Ali Syahbana menggunakan DFD (Data Flow Diagram) sedangkan pada penelitian ini menggunakan UML(Unified Modeling Language).

Persamaan penelitian yang dilakukan oleh Mafrida Rofiul Hayati, Migunani dan Fitro Nur Hakim yaitu dalam permasalahan penelitian yaitu sama-sama mengkat tentang sistem informasi pembayaran dan dalam membuat perancangan sistem menggunakan model $U M L$ dan bahasa pemrograman yang digunakan juga menggunakan bahasa pemrograman web. Sedangkan perbedaan penelitian Mafrida Rofiul Hayati, Migunani dan Fitro Nur Hakim adalah objek penelitian.

Penelitian yang dilakukan Prakoso dan Herlawati memiliki persamaan dengan penelitian ini yaitu dalam permasalahan penelitian yaitu sama-sama mengangkat tentang sisem informasi pembayaran. Sedangkan perbedaan dengan penelelitian ini adalah adanya penambahan fasilitas untuk memberikan informasi langsung kepada orang tua atau wali melalui sms gateway.

\section{Metodologi}

\subsection{Alur Penelitian}

Alur penelitian pada penelitian ini penulis menggunakan kerangka kerja sebagai berikut :

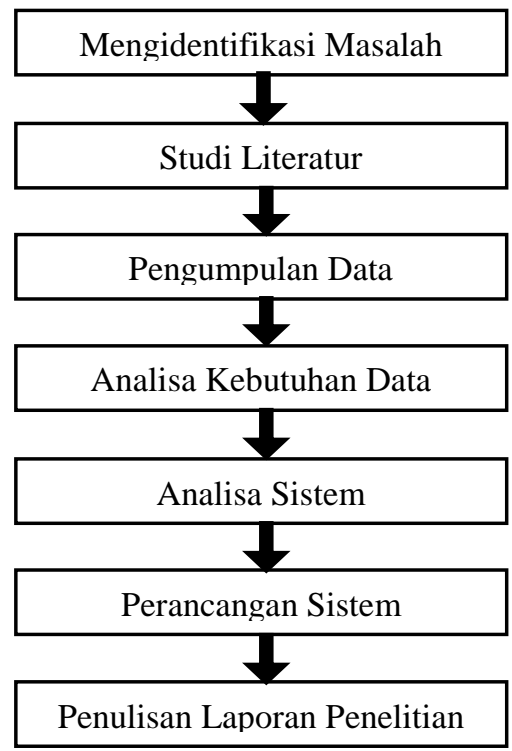

Gambar 1. Kerangka Kerja Penelitian

1. Mengidetifikasi Masalah

Dalam tahap ini, peneliti mengidentifikasi permasalahan yang ada yaitu merumuskan masalah yang akan di teliti. Dengan adanya perumusan masalah, maka penelitian akan menjadi jelas dan terarah.

2. Studi Literatur

Kegiatan ini dilakukan dengan maksud mempelajari dan memahami teori-teori yang menjadi pedoman dan referensi guna penyelesaian masalah yang di bahas dalam tesis ini dan mempelajari penelitian yang relevan dengan masalah yang diteliti.

3. Pengumpulan Data

Sebagai bahan pendukung untuk mencari atau mengumpulkan data yang diperlukan dalam penelitian ini, penulis menggunakan 2(dua) cara, yaitu :

a. Observasi

Jurnal Manajemen Sistem Informasi Vol.4, No.2, Juni 2019 
Observasi atau pengamatan adalah pengambilan data dengan melakukan pengamatan dan tanpa mengajukan pertanyaan kepada responden (Sekaran, 2006: 102). Observasi dilakukan dengan cara mencari data secara langsung di lapangan yang bertujuan untuk mengetahui secara langsung mengenai administrasi pembayaran biaya pendidikan yang ada pada Pondok Pesantren Nurul Iman.

b. Wawancara

Wawancara adalah cara pengumpulan data dengan mengajukan pertanyaan kepada responden untuk memperoleh informasi mengenai isu yang diteliti (Sekaran, 2006: 67).

Dalam penelitian ini wawancara dilakukan dengan cara mengajukan pertanyaan secara lisan kepada pihak yang terkait dengan pokok permasalahan. Wawancara ini dilakukan dengan berdialog langsung dengan petugas TU pada Pondok Pesantren Nurul Iman, kemudian dicatat seperlunya guna memperoleh informasi tertulis atau lisan mengenai administrasi pembayaran biaya pendidikan pada Pondok Pesantren Nurul Iman.

4. Analisa Kebutuhan Data

Pada tahap ini dilakukan analisa atas data-data yang telah didapat untuk memperoleh data yang benar-benar dibutuhkan dalam penelitian. Hal ini dilakukan dengan tujuan mengelompokan datadata tersebut untuk memperoleh kesimpulan yang valid dan relevan.

5. Analisa Sistem

Pada langkah ini dilakukan analisa terhadap sistem informasi yang sedang berjalan di Pondok Pesantren Nurul Iman saat ini. Hal ini dilakukan bertujuan untuk mengetahui masalah yang ada pada Sistem Informasi Administrasi Pembayaran biaya pendidikan di Pondok Pesantren Nurul Iman, sehingga diketahui apa saja kelemahan dan kekuangan yang terdapat pada sistem informasi tersebut.

Selain itu juga dilakukan analisa terhadap interaksi-interaksi yang terjadi di dalam sistem informasi administrasi pembayaran biaya pendidikan tersebut yang nantinya akan digambarkan dalam model UML, yaitu : diagram Use Case, Diagram Activity dan diagram class.

6. Perancangan Sistem

Pada tahap ini dibuat perancangan database pada sistem dan juga perancangan prototype sistem berupa user interface dengan menggunakan aplikasi Adobe Dreamweaver dan phpMySQL, sehingga tercipta sebuah layout Rancangan Sistem Informasi Administrasi Pembayaran biaya pendidikan berbasis Web dan SMS Gateway.

7. Penulisan Laporan Penelitian

Tahapan berikutnya yang dilakukan dalam penelitian ini yaitu membuat laporan penelitian dan menarik kesimpulan dari hasil penelitian yang mana akan menghasilkan dokumen-dokumen laporan.

\section{Hasil dan Pembahasan}

\subsection{Analisa Sistem Yang Sedang Berjalan}

Dari kegiatan observasi dan wawancara yang telah dilakukan, dapat diketahui bahwa dalam kegiatan administrasi pembayaran biaya pendidikan hingga saat ini masih menggunakan sistem pencatatan manual yang tentu saja mengalami berbagai kendala. Kendala yang paling sering dirasakan adalah petugas mengalami kesulitan dalam hal pencatatan dan pelaporan kepada pimpinan. Kendala lain yang muncul adalah pencarian data pembayaran santri membutuhkan waktu yang cukup lama dikarenakan data pembayaran dicatat pada sebuah buku sehingga petugas harus mencari data satu persatu.

Saat ini informasi pembayaran hanya disampaikan kepada santri, kemudian santri menyampaikan kepada orang tua atau walinya. Terkadang ada beberapa santri tidak menyampaikan informasi ini kepada orang tua atau walinya, sehingga orang tua atau wali santri tidak mengetahui informasi tentang pembayaran tersebut.

\subsection{Analisa Kebutuhan Sistem}

Berdasarkan permasalahan yang dibahas sebelumnya, maka solusi permasalahan yang diusulkan adalah dengan membuat perancangan Sistem Informasi Administrasi pembayaran biaya pendidikan yang 
berkerja secara terkomputerisasi, dimana Sistem Informasi dirancang berbasis web dan mendukung fitur sms gateway.

Kegiatan analisa kebutuhan sistem ini merupakan proses pemecahan sistem menjadi beberapa sub sistem yang lingkupnya lebih kecil, agar lebih mudah dalam mengidentifikasikan permasalahan-permasalahan, hambatan-hambatan, dan kesempatan-kesempatan yang ada dalam sistem, serta untuk mengetahui kebutuhan-kebutuhan sistem. Sehingga pada akhirnya nanti akan bisa diusulkan metode-metode perbaikan pada sistem. Tahap ini merupakan salah satu tahap yang penting, karena kesalahan dalam mengidentifikasikan permasalahan dalam sistem akan menimbulkan salah persepsi ketika ingin merancang sistem. Hal ini akan berakibat pada kurang efektifnya perancangan yang dibuat.

Pada bagian ini akan diperlihatkan bagaimana proses sistem yang terjadi sebenarnya, serta identifikasi kebutuhan-kebutuhan sistem, baik kebutuhan fungsional maupun kebutuhan non fungsional.

\subsection{Kebutuhan Fungsional Sistem}

Pemodelan fungsional sistem menggambarkan proses atau fungsi yang harus dikerjakan oleh sistem untuk melayani kebutuhan pengguna (user). Berdasarkan kebutuhan diketahui bahwa user yang menggunakan sistem terdiri dari admin dan petugas TU yang melakukan fungsi utama sebagai berikut :

1. Admin

Fungsionalitas sistem untuk admin adalah sebagai berikut :

a. Fungsi Login

Digunakan oleh admin untuk masuk kedalam sistem.

b. Fungsi Mengelola Data Petugas TU

Digunakan oleh admin untuk menambah, mengubah dan menghapus informasi yang berkaitan dengan data petugas TU pada sistem dan disimpan pada database system.

c. Fungsi Mengelola Data Akses Petugas TU

Digunakan oleh admin untuk mengelola data akses petugas TU.

d. Fungsi Mengelola Data Jenis Pembayaran Biaya Pendidikan

Digunakan oleh admin untuk menambah, mengubah dan menghapus informasi yang berkaitan dengan data jenis pembayaran biaya pendidikan pada sistem dan disimpan pada database system.

e. Fungsi Mengelola Data Periode Pembayaran Biaya Pendidikan

Digunakan oleh admin untuk menambah, mengubah dan menghapus informasi yang berkaitan dengan data periode pembayaran biaya pendidikan pada sistem dan disimpan pada database system.

f. Fungsi Logout

Digunakan oleh admin untuk logout atau keluar dari sistem.

2. Petugas TU

a. Fungsi Login

Digunakan oleh petugas TU untuk masuk kedalam sistem.

b. Fungsi Mengelola Data Santri

Digunakan oleh petugas TU untuk menambah, mengubah dan menghapus informasi yang berkaitan dengan data Santri pada sistem dan disimpan pada database system.

c. Fungsi Mengelola Data Wali Santri

Digunakan oleh petugas TU untuk menambah, mengubah dan menghapus informasi yang berkaitan dengan data Wali Santri pada sistem dan disimpan pada database system.

d. Fungsi Mengelola Data Keringanan Pembayaran Biaya Pendidikan

Digunakan oleh petugas TU untuk mnambah, mengubah dan menghapus informasi yang berkaitan dengan data Keringanan Pembayaran Biaya Pendidikan pada sistem dan disimpan pada database system.

e. Fungsi Mengelola Data Transaksi Pembayaran Biaya Pendidikan

Digunakan oleh petugas TU untuk menambah, mengubah dan menghapus informasi yang berkaitan dengan data transaksi pembayaran biaya pendidikan pada sistem dan disimpan pada database system.

f. Fungsi Cetak Slip Transaksi Pembayaran Biaya Pendidikan Digunakan oleh petugas TU untuk mencetak slip transaksi pembayaran biaya pendidikan.

g. Fungsi Cetak Laporan Rekapitulasi Pembayaran Biaya Pendidikan 
Digunakan oleh petugas TU untuk mencetak laporan rekapitulasi pembayaran biaya pendidikan.

h. Fungsi Cetak Laporan Rekapitulasi Tunggakan Biaya Pendidikan

Digunakan oleh petugas TU untuk mencetak laporan rekapitulasi tunggakan biaya pendidikan

i. Fungsi mengirim SMS ke Wali Santri

Digunakan oleh petugas TU untuk mengirim informasi pembayaran melalui SMS ke Wali Santri.

j. $\quad$ Fungsi Logout

Digunakan oleh petugas TU untuk logout atau keluar dari sistem.

\subsection{Kebutuhan Non Fungsional Sistem}

Kebutuhan non fungsional sistem dapat menjadi lebih kritis dari fungsional sistem, dimana jika tidak terpenuhi maka sistem tidak dapat digunakan. Berdasarkan kebutuhan fungsional sistem yang telah dijelaskan sebelumnya, maka diharapkan sistem yang dirancang mampu memiliki hal-hal berikut :

1. Usability

a. Mudah digunakan oleh admin atau petugas TU dalam mengelola dan memberikan informasi mengenai transaksi pembayaran biaya pendidikan.

b. Informasi mengenai pembayaran biaya pendidikan dapat dengan mudah langsung disampaikan ke wali santri.

2. Functionality

a. Mempermudah dalam memberikan informasi.

b. Sistem mudah digunakan oleh admin dan petugas TU.

3. Security

a. Setiap admin dan petugas TU diberi username dan password untuk mengolah informasi.

\subsection{Diagram Use Case}

Model diagram use case ditentukan atas dasar kebutuhan fungsi-fungsi yang akan dibangun. Berdasarkan asumsi yang digunakan dapat digambarkan diagram use case sistem informasi administrasi pembayaran biaya pendidikan pada Pondok Pesantren Nurul Iman adalah sebagai berikut : 


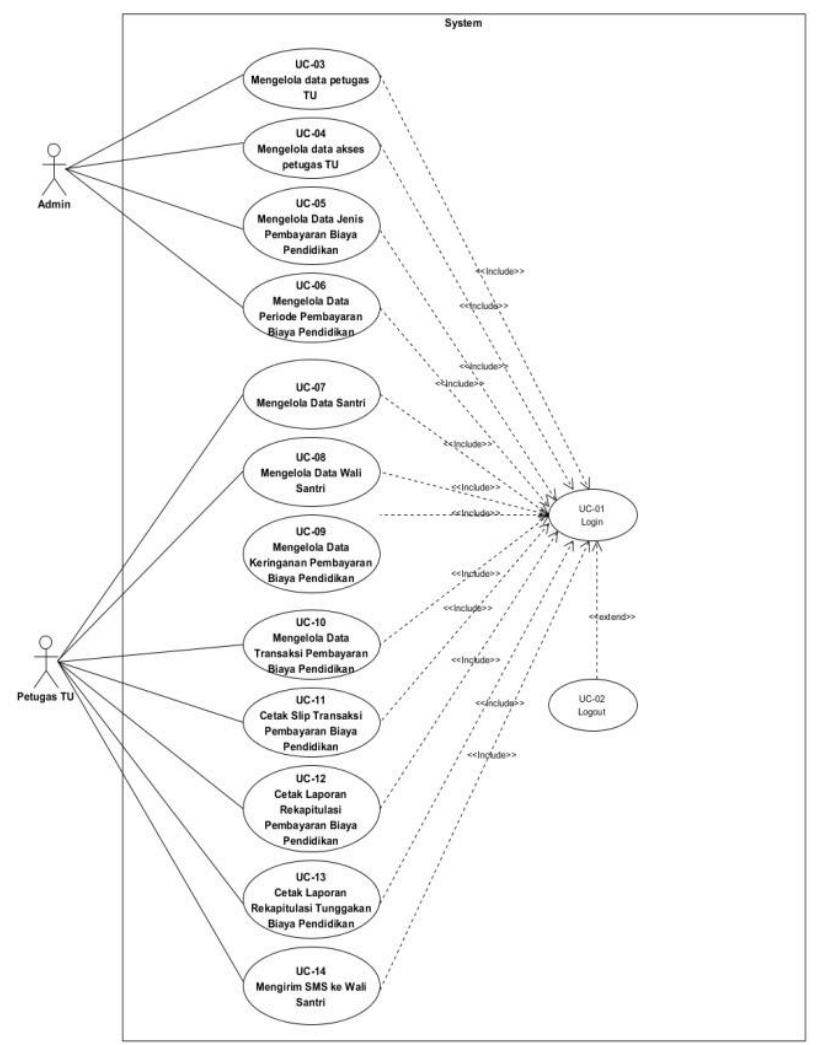

Gambar 2. Diagram Use Case Sistem Informasi Administrasi Pembayaran Biaya Pendidikan Pada Pondok Pesantren Nurul Iman 
Diagram Acivity

Diagram acivity akan menggambarkan aliran kerja dari sistem informasi yang akan dirancang. Sistem Informasi Administrasi Pembayaran Biaya Pendidikan Pada Pondok Pesantren Nurul Iman adalah digambarkan berdasarkan algoritma dalam subsistem.

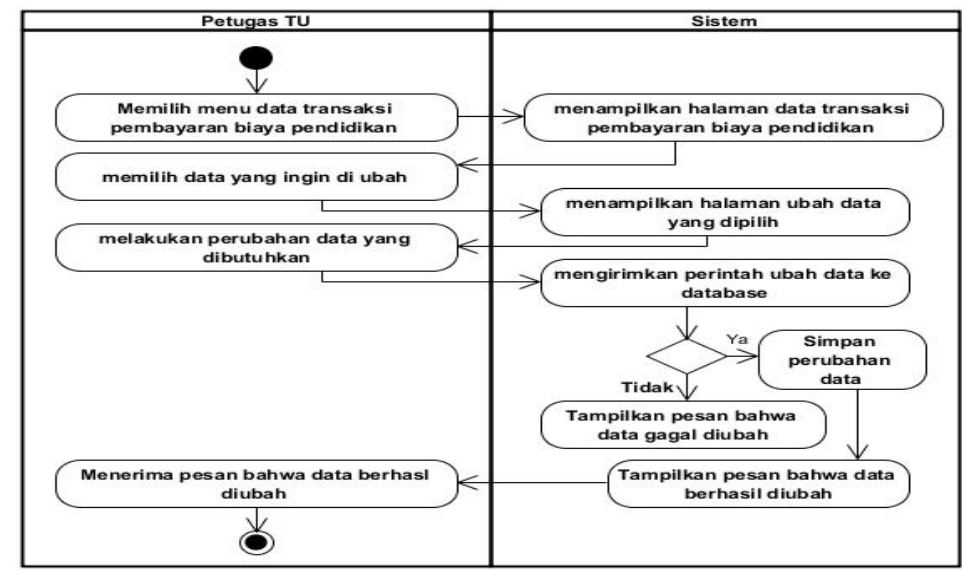

Gambar 3. Diagram Activity Menambah Data transaksi pembayaran biaya pendidikan

\subsection{Diagram Class}

Diagram class menggambarkan class berikut perilaku dan keadaan dengan menghubungkannya antar class-class yang terdapat dalam sistem. Pada bagian ini akan digambarkan diagram class yang terdapat dalam Sistem Informasi Administrasi Pembayaran Biaya Pendidikan Pada Pondok Pesantren Nurul Iman seperti gambar di bawah ini:

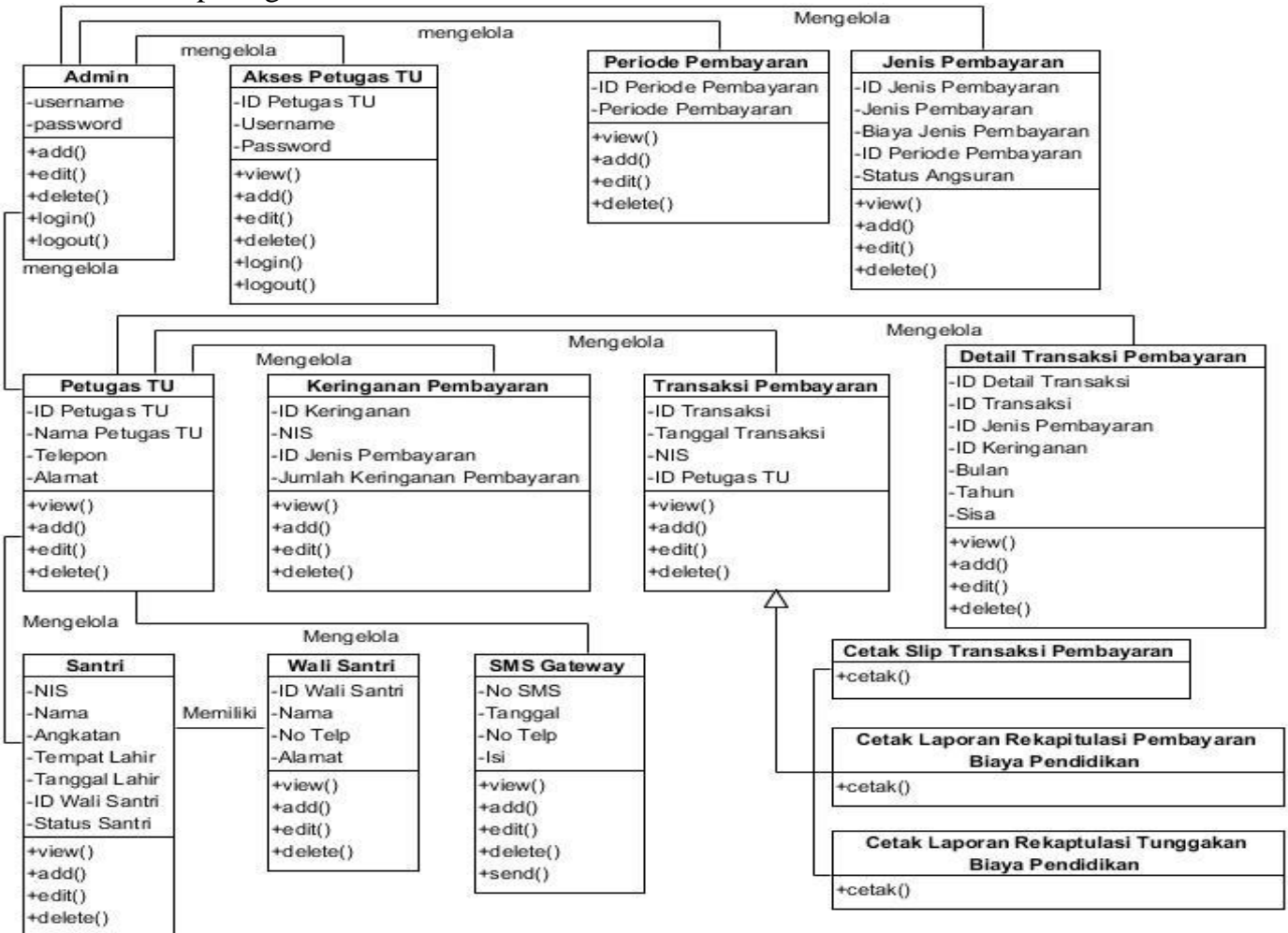

Gambar 4. Diagram class pada Sistem Informasi Pembayaran Biaya Pendidikan pada Pondok Pesantren Nurul Iman 


\subsection{Protoype Sistem}

Prototype adalah suatu versi sistem potensial yang disediakan bagi pengembang dan calon pengguna yang dapat memberikan gambaran bagaimana sistem tersebut akan berfungsi bila telah disusun dalam bentuk yang lengkap.

Berdasarkan rancangan sistem yang telah diuraikan sebelumnya, maka perlu dibangun prototype dari Sistem Informasi Pembayaran Biaya Pendidikan pada Pondok Pesantren Nurul Iman. Adapun tampilan Sistem Informasi Pembayaran Biaya Pendidikan pada Pondok Pesantren Nurul Iman dapat dilihat sebagai berikut:

1. Halaman Login

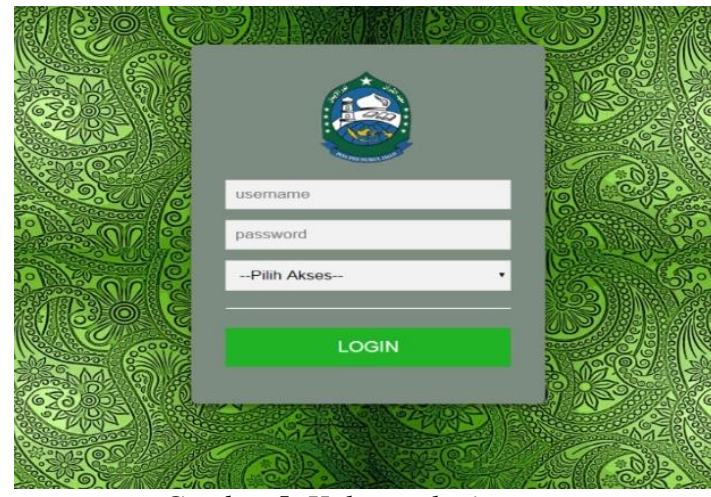

Gambar 5. Halaman login

Berdasarkan gambar tampilan halaman login, halaman ini digunakan untuk menghindari perubahan data atau pengambilan data oleh pihak yang tidak bertanggung jawab. Setiap pengguna harus memasukkan username, password dan hak akses yang benar untuk dapat mengelola data.

\section{Halaman Utama}

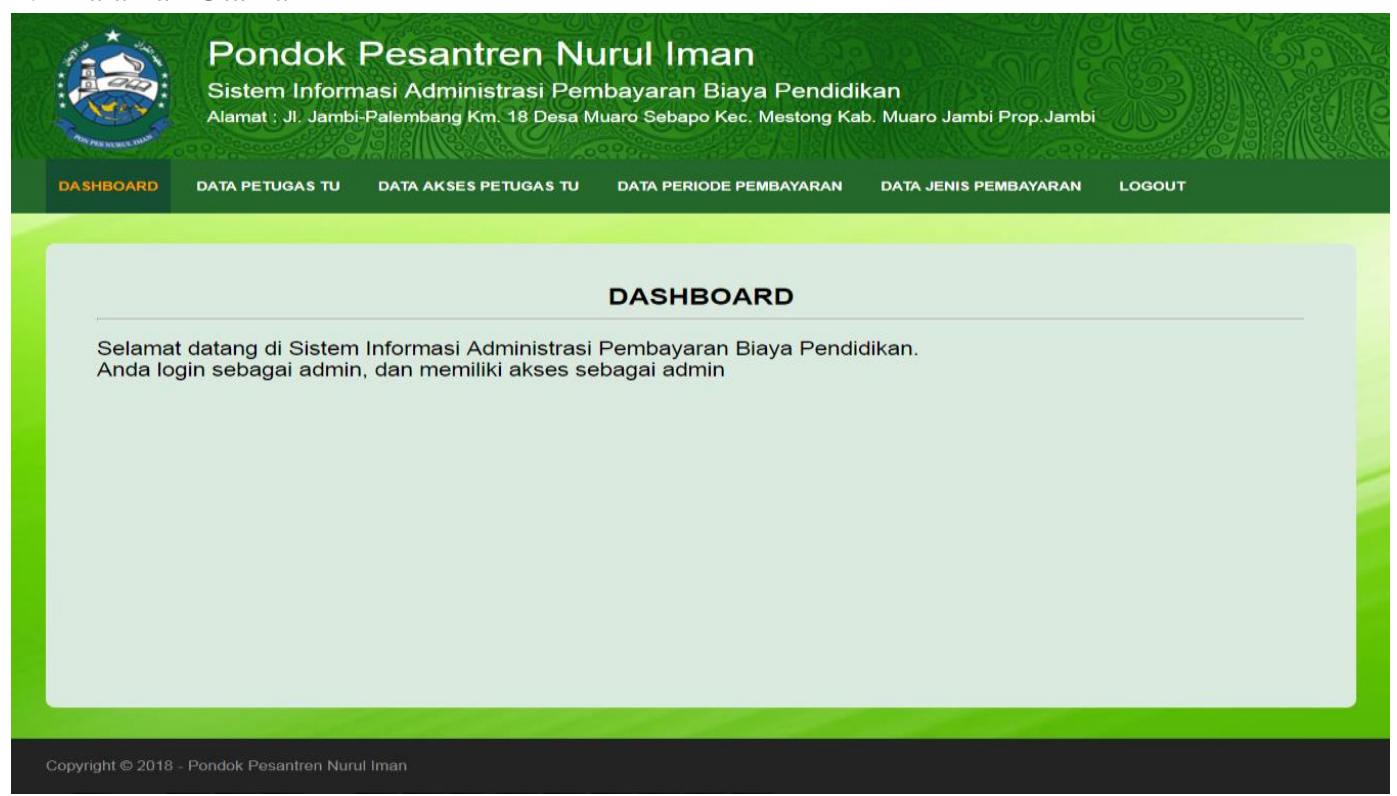

Gambar 6. Halaman utama

Berdasarkan gambar tampilan halaman utama admin, dapat diketahui bahwa terdapat penjelasan mengenai siapa user yang login dan hak akses yang dimiliki oleh user tersebut. Pada halaman ini juga ditampilkan informasi tentang sistem informasi administrasi pembayaran biaya pendidikan pada Pondok Pesantren Nurul Iman. 
3. Halaman Tambah transaksi pembayaran

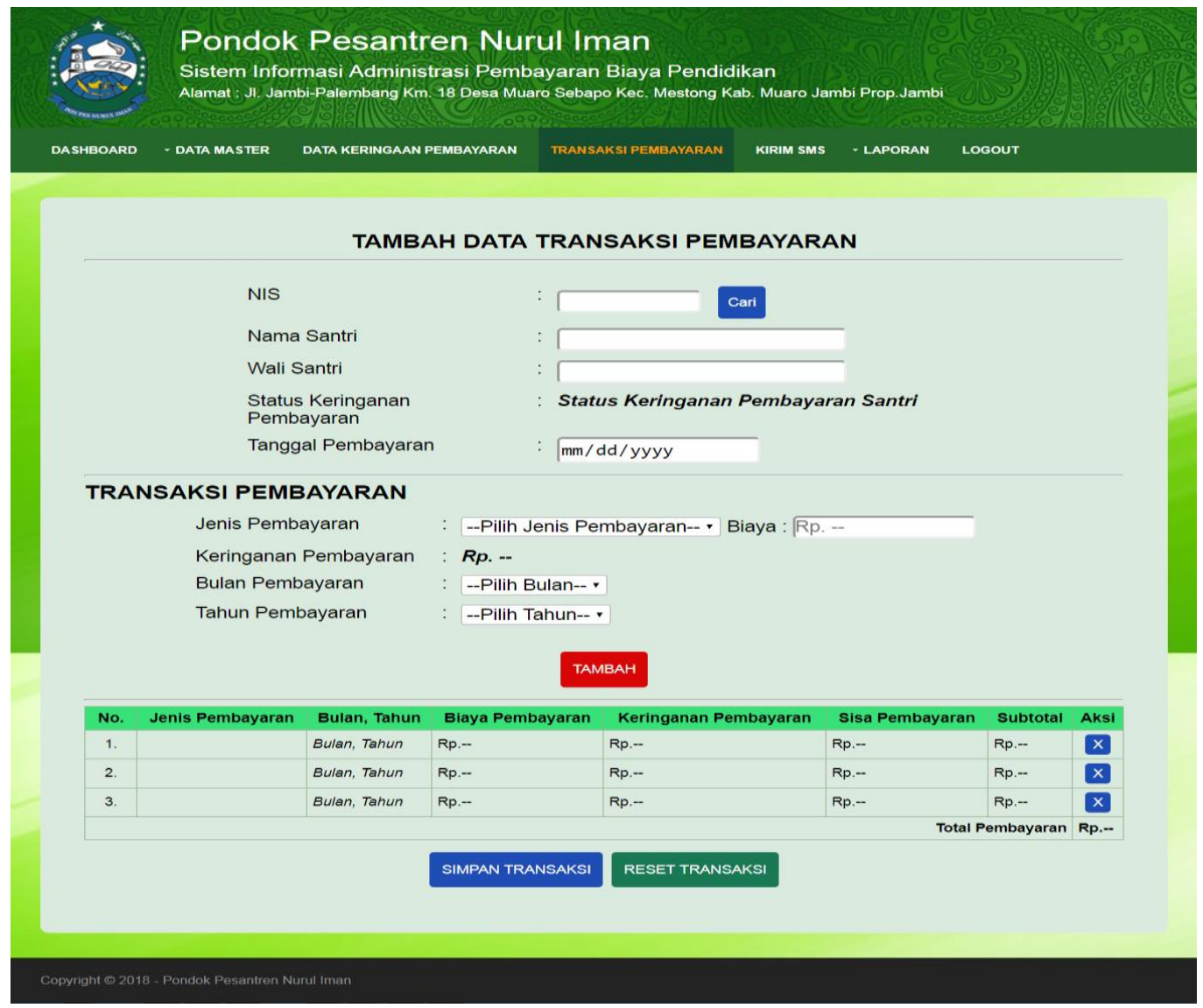

Gambar 7. Halaman tambah transaksi pembayaran

\section{Kesimpulan}

\subsection{Simpulan}

Berdasarkan analisis dan perancangan sistem informasi administrasi pembayaran biaya pendidikan yang dilakukan pada Pondok Pesantren Nurul Iman, maka dapat ditarik kesimpulan sebagai berikut :

1. Kegiatan administrasi pembayaran biaya pendidikan yang ada pada Pondok Pesantren Nurul Iman belum didukung oleh sistem informasi yang memadai, sehingga belum dapat menunjang kebutuhan sistem untuk daya saing yang berkelanjutan di masa yang akan datang.

2. Penelitian ini menghasilkan sebuah prototype sistem informasi administrasi pembayaran biaya pendidikan berbasis web dan sms gateway yang dapat diimplementasikan lebih lanjut sehingga menghasilkan sistem informasi administrasi pembayaran biaya pendidikan yang dapat diterapkan pada Pondok Pesantren Nurul Iman.

3. Prototype sistem informasi administrasi pembayaran biaya pendidikan pada Pondok Pesantren Nurul Iman ini menyediakan layanan - layanan berupa informasi yang terdiri dari : slip transaksi pembayaran, rekapitulasi transaksi pembayaran biaya pendidikan, rekapitulasi tunggakan pembayaran biaya pendidikan dan dapat memberikan informasi pembayaran kepada wali santri melalui fasilitas sms gateway.

\subsection{Saran}

Berdasarkan penelitian yang telah dilakukan maka dapat dikemukakan saran-saran sebagai berikut :

1. Prototype sistem ini perlu dikembangkan, sehingga benar - benar dapat diterapkan pada Pondok Pesantren Nurul Iman untuk mendukung seluruh proses bisnis dari sistem informasi administrasi 
pembayaran biaya pendidikan pada Pondok Pesantren Nurul Iman berbasis web dan sms gateway.

2. Dalam pembuatan prototype ini belum memperhatikan masalah keamanan data (security), maka untuk penelitian lebih lanjut dapat dilengkapi dengan sistem keamanan data.

\section{Daftar Rujukan}

[1] Basuki, Awan Pribadi. 2016. Membangun Aplikasi SMS Gateway Berbasis Web dengan Codeigniter \& Bootstrap. Yogyakarta : Penerbit Lokomedia.

[2] Bishop, Sherry. 2011. Adobe Dreamweaver CS5. Illustrated Series. USA : Course Technology.

[3] Connolly, Thomas; \& Begg, Carolyn. 2015. Database Systems: A Practical Approach to Design, Implementation, and Management, Sixth Edition. Boston : Pearson Education.

[4] Dennis, Alan; Wixom, Haley Barbara; \& Roth, Roberta M. 2009. Systems Analysis and Design, Fifth Edition. United States of America : John Wiley \& Sons, Inc.

[5] Elmasri, Ramez;\& Navathe, Shamkant B. 2004. Fundamentals Of Database Systems, Fourth Edition. Boston : Pearson Education.

[6] Hayati, Mafrida Rofiul; Migunani; \& Hakim, Fitro Nur. 2013. Sistem Informasi Pembayaran Spp Berbasis Web Dan Sms Broadcast (Studi Kasus: SMP Muhammadiyah 03 semarang). Jurnal Teknologi Informasi dan Komunikasi, Volume 4, Nomor 2. Semarang : Program Studi Teknik Informatika STMIK ProVisi Semarang.

[7] Jogiyanto HM. 2005. Analisis \& Desain Sistem Informasi : Pendekatan Terstruktur, Teori dan Praktik Aplikasi Bisnis. Yogyakarta : Andi Publisher.

[8] Kadir, Abdul. 2014. Pengenalan Sistem Informasi edisi Revisi. Yogyakarta : Andi Offset.

[9] Kendall, E. Kenneth; \& Kendall, E. Julie. 2011. Systems Analysis and Design. Eighth Edition. United States of America : Pearson Education Inc.

[10] Kusrini;\& Koniyo, A. 2007. Tuntunan Praktis Membangun Sistem Informasi dengan Visual Basic dan Microsoft SQL Server. Yogyakarta : Andi Offset.

[11] Laudon, C. Kenneth; \& P. Laudon, Jane. 2016. Management Information Systems:Managing The Digital Firm, Fourteenth Edition. England : Pearson Education Limited.

[12] Munawar. 2005. Pemodelan Visual dengan UML. Yogyakarta : Graha Ilmu.

[13] McLeod, Jr. Raymond; \& P. Schell, George. 2007. Management Information Systems. Tenth Edition. New Jersey, United States of America : Pearson Prentice Hall.

[14] Oetomo, Budi Sutedjo Dharma. 2006. Perencanaan \& Pengembangan Sistem Informasi. Yogyakarta : Penerbit Andi.

[15] Prakoso, Merza Dheo; \& Herlawati. 2017. Sistem Informasi Biaya Pendidikan Siswa Pada SMK Perwira Bangsa Bekasi Utara. Bina Insani ICT Jurnal. Volume 4, Nomor 1. Bekasi : STMIK Bina Insani.

[16] Pedoman Administrasi Pembayaran Biaya Pendidikan Santri Pondok Pesantren Nurul Iman.

[17] Rawung, Frangky. 2017. Buku Pintar Aplikasi SMS dengan PHP dan MySQL. Surabaya : Penerbit Gava Media.

[18] Rosa. A.S. ;\& Shalahuddin. M. 2013. Rekayasa Perangkat Lunak: Terstruktur Dan Berorientasi Objek. Bandung : Penerbit Informatika.

[19] Rosdiana; Daeli, Dinizta Malini;\& Kusen, Axel Desmond. 2016. Desain Aplikasi Pembayaran Spp Dengan Laporan Sms Gateway Di Smk Sakti School. Yang dipresentasikan pada Seminar Nasional Teknologi Informasi, Bisnis, dan Desain. Tangerang : STMIK - Politeknik PalComTech.

[20] Shelly, Gary B; Wells, Dolores J; \& Campbell, Jennifer T. 2012. Adobe Dreamweaver CS5 Comprehensive. USA : Course Technology.

[21] Stair, Ralph; \& Reynolds, George. 2010. Principles of Information Systems A Managerial Approach. Ninth Edition. Canada: Nelson Education, Ltd. 
[22] Supono; \& Putratama. Virdiandry. 2016. Pemrograman Web Dengan Menggunakan PHP dan Framework Codeigniter. Yogyakarta : Penerbit Deepublish.

[23] Syahbana, Ali. 2013. Pembangunan Sistem Informasi Administrasi Pembayaran Siswa Madrasah Aliyah Ma'arif Pacitan. Jurnal Speed - Sentra Penelitian Engineering dan Edukasi, Volume 5, Nomor 3. Surakarta : Universitas Surakarta.

Jurnal Manajemen Sistem Informasi Vol.4, No.2, Juni 2019 